\title{
China's Role in the Evolution of Southeast Asian Regional Organizations
}

\section{Claudia Astarita}

\section{(2) OpenEdition \\ 1 Journals}

\section{Electronic version}

URL: http://journals.openedition.org/chinaperspectives/4103

DOI: 10.4000/chinaperspectives.4103

ISSN: 1996-4617

\section{Publisher}

Centre d'étude français sur la Chine contemporaine

\section{Printed version}

Date of publication: 1 July 2008

Number of pages: $78-86$

ISSN: 2070-3449

\section{Electronic reference}

Claudia Astarita, "China's Role in the Evolution of Southeast Asian Regional Organizations », China Perspectives [Online], 2008/3 | 2008, Online since 01 July 2011, connection on 10 December 2020. URL : http://journals.openedition.org/chinaperspectives/4103; DOI : https://doi.org/10.4000/ chinaperspectives.4103 
C

China's Role in the Evolution

of Southeast Asian Regional

Organizations

\author{
CLAUDIA ASTARITA
}

Geographically and strategically, Southeast Asia represents the natural extension of China's interests in the region. In the course of discussing China's role in four regional organizations, ASEAN, ARF, ASEAN +3, and EAS, its interactions with the United States, Japan, and India will be reviewed as well. The goal of this paper is to consider whether or not China has maintained and is maintaining a dominant position within these fora.

$\mathrm{T}$ oday more then ever, South, Central, West, and Southeast Asia are crucial gateways for China to access natural resources and sea routes that can guarantee regular trade flows and stable economic growth. China's regional neighbours, however, often join forces to prevent China from affirming and protecting its own interests in these areas.

Rather than choosing the option of open competition, China has progressively adopted a cooperative multilateral approach in the region, and is now involved in several regional organizations. Within these fora, China interacts with other Asian countries and negotiates common policies and strategies with them. In most cases, China retains its status as the most powerful country in the region, and can easily affirm its interests and points of view. However, as Asian countries share a long tradition of mutual suspicion and mistrust, these arenas have progressively shown their usefulness in regional confidence-building by substantially easing some of the mutual misunderstandings and sources of mistrust between Asian nations.

The aim of this paper is to focus on China's ambitions and achievements in Southeast Asia through a review of four international groupings: the Association of Southeast Asian Nations (ASEAN), with special attention to the ChinaASEAN framework; the Asian Regional Forum (ARF); the ASEAN+3 platform; and the East Asian Summit (EAS). This structure will allow a brief additional overview of China's interactions with three prominent powers: the United States, Japan, and India. The role these countries are playing in ARF, ASEAN+3, and EAS, respectively, cannot be neglected in an analysis of China's regional interests, aims, and targets. In addition, whether China is achieving its objectives or not depends on how and to what extent these three countries are counterbalancing Chinese influence in the region, and their bilateral and multilateral interactions deeply affect the consolidation of Asian regional integration.

\section{China and ASEAN: From animosity to cooperation}

Although China is widely recognized today as having strong and developed links with ASEAN countries, it is useful to remember that the seed of ASEAN was the strong anticommunist feeling shared by Southeast Asian nations.

ASEAN was set up in Bangkok on 8 August 1967 by the governments of Indonesia, Thailand, Malaysia, Singapore, and the Philippines. It has been documented that "ASEAN's founding purpose was to ensure the survival of its members by promoting regional stability and limiting competition between them." (I) The Bangkok Declaration specified that ASEAN was not an appropriate forum to handle security matters or political controversies. On the contrary, Southeast Asian countries defined three strategies oriented at reducing "the appeal of internal Communist insurgencies by promoting socio-economic development," limiting "the regional military influence of external actors," and reducing

1. Shaun Narine, Explaining ASEAN. Regionalism in Southeast Asia, London, Rienner Publisher, Inc., 2002, pp. 12-13. 
"intra-ASEAN competition and improving relationships between members." ${ }^{(2)}$ According to some other scholars, in 1967, "on the initiative of (Indonesian) President Suharto (...) ASEAN was set up to counter China which was very aggressive in sponsoring 'revolutionary movements' across Southeast Asia." ${ }^{(3)}$

In essence, ASEAN nations became cautious and suspicious when, "from the mid 1960s to the mid 1970s, Beijing placed ideological alignment over state-to-state relations by supporting Communist insurgents in non-communist countries." (4) However, the realignment between China and the United States in the early 1970s, and Deng Xiaoping's launch of economic reform and the accompanying open-door policy in 1978, created more trust (and economic opportunities) for Southeast Asian countries. Indeed, China normalised relations with most of them in the 1970s, and the delicate issue of "overseas Chinese" was resolved. In the 1980s, Deng Xiaoping regarded Singapore as the model for Chinese development, and some Southeast Asian countries such as Indonesia, Malaysia, and Thailand began considering China "a security concern, though not as serious as before." ${ }^{(5)}$

Despite these improvements, however, the issue of the Spratly Islands, a group of more than 100 reefs, islets, and islands in the South China Sea with a total area of less than five square kilometres, has remained unresolved throughout these decades. "The post-war dispute over (these islands) originated from the 1951 San Francisco peace agreement, which failed to stipulate who was to possess the Spratlys after Japan." ${ }^{(6)}$ At that time, six governments claimed partial sovereignty over these islands: Vietnam, the Philippines, Brunei, Malaysia, China, and Taiwan. In the case of the Spratlys, sovereignty was claimed not merely for the sake of its rich fisheries, but rather to attain "the legal right to control and develop the area's energy resources, which (all these countries needed) to fuel their rapid economic development." (7) China's victory in its skirmish with Vietnam in 1988, and its occupation of the Philippine-claimed Mischief Reef in 1995, "implied that the balance of power in the region was changing to the advantage of China." ${ }^{(8)}$ Moreover, Southeast Asian countries' disagreements on the issue highlighted the need for dialogue. ${ }^{(9)}$

The situation finally improved in the early twenty-first century after China and ASEAN agreed to create a code of conduct aimed at easing tensions over the disputed islands. In November 2002, a Declaration on the Conduct of Parties in the South China Sea was signed, and all countries "recognized the need to promote a peaceful, friendly and harmonious environment in the South China Sea between them for the enhancement of peace, stability, economic growth and prosperity in the region." ${ }^{(10)}$ However, the Spratly Islands remain a source of concern, since the 2002 agreement lacks a legally binding code of conduct. Furthermore, in recent years China has strengthened military control over occupied islands, islets, and other waters, and has stepped up exploration and exploitation of natural resources in the region. At the same time, "world powers such as the U.S., Japan and India have increased their military infiltration in the South China Sea regions, pushing the issue towards a more complicated and internationalized level." (II)

From the perspective of economic cooperation, 1997 was a pivotal year for China-ASEAN relations. It is usually remembered as the year in which "leaders from ASEAN countries and China held the first informal Summit in Kuala Lumpur (Malaysia) to officially recognize the ASEANChina process and to adopt the strategy of "good neighborliness' and 'mutual trust' to strengthen and expand ASEANChina ties in the twenty-first century." ${ }^{(12)}$ The Asian financial crisis in 1997 gave China a further opportunity to offer help to Southeast Asian countries. Following the Thai government's failure to stop the collapse of the Thai baht against the US dollar, the financial crisis rapidly spread to South Korea, Indonesia, Malaysia, Laos, the Philippines, and Hong Kong as well, forcing most of these countries to float their currencies. The crisis also generated panic among borrowers, a collapse of demand, and a loss of confidence throughout the region. Moreover, even a potential "exportdriven recovery, benefiting from the devalued currencies and improved competitiveness, was blocked by the fact that many firms had no access to credit for importing raw materials,"

2. Ibid., pp. 12-15

3. Ignatius Wibowo Wibisono, "ASEAN-China Relations: Indonesia's Perspective," in Lai Hongyi et al. , Harmony and Development: ASEAN-China Relations, Singapore, World Scientific, p. 78

4. Lai Hongyi et al., "ASEAN and China: Towards a Harmonious Relationship," in Lai Hongyi et al., op. cit., p. xvii.

5. Lai Hongyi, "China's Evolving Relations with Southeast Asia," in Lai Hongyi et al., op. cit., pp. 20-21.

6. Liselotte Odgaard, "Deterrence and Co-operation in the South China Sea," Contemporary Southeast Asia, Vol. 23, n. 2, August 2001, pp. 293-4.

7. Chien-peng Chung, "South China Sea Islands Disputes," The Journal of Social, Political and Economic Studies, Vol. 24, n. 1, Spring 1999, p. 19

8. Liselotte Odgaard, op. cit., p. 294.

9. Ibid., p. 300

10. China, ASEAN sign code of conduct on South China Sea, Xinhua, 4 November 2002.

11. "The Worrisome Situation of the South China Sea - China Facing the Stepped-up Military Infiltration by the U.S., Japan and India," Outlook East Weekly, 12 January 2004

12. Lai Hongyi et al., "ASEAN and China: Towards a Harmonious Relationship," in Lai Hongyi et al., op. cit., p. xix. 


\section{SIGNING CEREMONY}

\section{ASEAN-CHINA}

\section{November 2002}

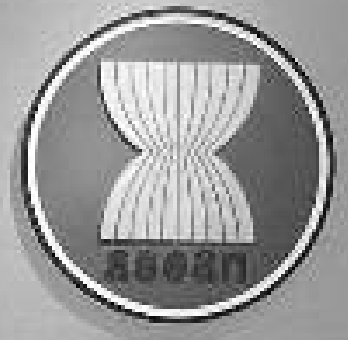

\section{Phnom Penh, Cambodia}


quently consider ASEAN countries as alternative economic partners. ${ }^{(21)}$

The continuing development of ASEAN nations and the strong economic performance of the Chinese economy led ASEANChina bilateral trade to grow at a rate of about 17 percent per year from 1991 to 2000 , and 20 percent from 2001 to 2007 . $^{(22)}$ During the last 15 years, China has also committed itself to easing the economic divide between new and old ASEAN members. ${ }^{(23)}$ Indeed, "in 2003 the average per-capita GDP in the ASEAN-6 was US\$1,626 compared with US\$356 in the ASEAN-4," not to mention disparities in economic size and the purchasing power of national currencies. ${ }^{(24)}$ At the same time, some ASEAN nations complained that regional economic integration with China had forced local companies out of the market. ${ }^{(25)}$ However, China replied to these statements by noting that the trade balance between China and ASEAN strongly favoured Southeast Asian countries, showing that China was an economic partner that ASEAN could not easily dismiss. ${ }^{(26)}$ Two improvements in China-ASEAN relations can be identified today. First, China has become the largest provider of Foreign Direct Investment (FDI) ${ }^{(27)}$ in most Southeast Asian countries. China is also financing most of the infrastructural projects in the region, partly out of a desire to prove itself a loyal partner in the economic development of the region, and partly because improvements in transportation infrastructure inevitably boost bilateral trade.

The second positive improvement is linked to the Agreement on ASEAN-China Comprehensive Economic Cooperation signed in 2002, under which a free trade zone (CAFTA) should be completed in 2010. ${ }^{(28)}$

Under this agreement, which affects 1.8 billion people, several protocols have been signed, and the tariff cut process already began in 2005. ${ }^{(29)}$ Since then, multilateral trade has steadily increased, and both sides are now discussing "setting up a number of economic trade cooperation zones in the ASEAN region to facilitate more intra-investments." ${ }^{(30)}$ Ideally, "CAFTA will increase the region's market appeal and further attract regional and non-regional FDI. (Further,) firms will be able to break up the value chain by distributing production stages throughout the region in a way that exploits the individual members' comparative advantages. Besides, subsidiaries will be able to enjoy greater economies of scale, thus making them more profitable." ${ }^{(3)}$

China's interest in Asia and in economic development within the region has recently created spill-over in membership and in the issues discussed in the fora. While taking note of the advantages of a deeply integrated region, Asian countries have also become wary of China's own interests, and have started engaging in a healthy competitive process. Japan, South Korea, India,
Australia, and New Zealand are all looking to involve themselves in regional fora. ${ }^{(32)}$ While all of these countries stand to benefit from broader economic integration, it is possible that their engagement policy has been chosen as much to counterbalance the Chinese presence in the region as it is to pursue their national interests. ${ }^{(33)}$

Before discussing the evolution of regional equilibrium in the ASEAN+3 and EAS platforms that involve all of the abovementioned countries, and explaining whether and how they are preventing China from fulfilling its aims, this paper will give an example of the second kind of spill-over China has created in the region, in which new international fora have been established in order to allow multilateral cooperation to expand beyond the scope of economic integration.

\section{China and ASEAN Regional Forum: First steps in security cooperation}

Following the path of regionalisation, the ASEAN Regional Forum (ARF) was established in 1994 to draw China into a regional security process. The ARF is an informal multi-

21. Until the 1980s ASEAN had only five members. Brunei joined ASEAN in 1984, Vietnam in 1995, Myanmar and Laos in 1997, and Cambodia in 1999. Lai Hongyi, "China’s Evolving Relations with Southeast Asia," in Lai Hongyi et al., op. cit., p. 24.

22. Lai Hongyi et al., "ASEAN and China: Towards a Harmonious Relationship," in Lai Hongyi et al., op. cit., p. xxv.

23. Ong Keong Yong, "Further Enhancing ASEAN-China Relations," in Lai Hongyi et al., op. cit., p. 8, and Jusuf Wanandi, "Overcoming Obstacles in ASEAN-China relations," in Lai Hongyi et al., op. cit., p. 12.

24. Melissa Curley et al., "Advancing East Asia regionalism: An introduction," in Melissa Curley et al., Advancing East Asian Regionalism, New York, Routledge, 2007, p. 20.

25. Sheng Lijun, "China's Peaceful Rise and its Political and Security Implications," in Lai Hongyi et al., op. cit..

26. Lai Hongyi, "China's Evolving Relations with Southeast Asia," in Lai Hongyi et al., op. cit., p. 29.

27. Ong Keong Yong, "Further Enhancing ASEAN-China Relations," in Lai Hongyi et al., op. cit., pp. 7-8, Liao Shaolian, "China-ASEAN Economic Relations: Progress and Prospects," in Lai Hongyi et al., op. cit., pp. 142-3.

28. In 2010 the Free Trade Area should involve Brunei, Indonesia, Malaysia, the Philippines, Singapore, Thailand, and China, while Cambodia, Laos, Myanmar, and Vietnam are supposed to join in 2015. Ong Keong Yong, "Further Enhancing ASEAN-China Relations," in Lai Hongyi et al., op. cit, p. 8, "Backgrounder: China-ASEAN Free Trade Area," Xinhua General News Service, 27 0ctober 2006.

29. Zhang Zhenjiang, "ASEAN-China relations and Development of East Asian Regionalism," in Lai Hongyi et. al., op. cit., p. 93.

30. Lu Jianren, "China's Economic Growth and its Impact on the ASEAN Economies," in Lai Hongyi et. al., op. cit., p. 113.

31. Liao Shaolian, "China-ASEAN Economic Relations: Progress and Prospects," in Lai Hongyi et. al., op. cit., p. 143.

32. Zhang Zhenjiang, "ASEAN-China relations and Development of East Asian Regionalism," in Lai Hongyi et. al., op. cit.

33. Claudio Landi, II dragone e l'elefante. Cina e India nel Secolo dell'Asia, Firenze, Passigli 2007, p. 14. 
lateral organization in which members (including the ASEAN countries, China, European Union, India, Japan, Pakistan, Russia, and the United States) seek to address security issues in the Asia-Pacific region.

Although the aim of the first meeting was to make "all participants - especially China - 'comfortable' with the process and the other states," the second meeting, in 1995, initiated discussions on the promotion of "confidence-building measures, the development of preventive diplomacy mechanism and conflict-resolution mechanism." ${ }^{(34)}$ However, the broad membership, with its cultural and political diversity, has proven a hindrance for achieving cooperation and the signing of agreements, and progress has been both difficult and slow.

Analysing China's role within the ARF provides an opportunity to discuss China-US bilateral relations, as this is one of two regional fora in which the United States is directly involved. The second forum is the Asia-Pacific Economic Cooperation (APEC), created in 1989 as a "consultative body whose aim was weighing the interests of the AsiaPacific countries against the Europeans in the General Agreement on Tariffs and Trade (GATT) negotiations." ${ }^{(35)}$ Since its foundation, APEC has tried to implement several initiatives aimed at dismantling trade barriers in the region; creating a dispute mediation mechanism; fostering monetary and macroeconomic cooperation; and compromising on technical cooperation projects for development of human resources, tourism, infrastructure, and energy. ${ }^{(36)}$ Despite its good intentions, its achievements have not been as significant as expected, mainly because of an excessively broad and diverse membership that includes countries whose deeply conflicting national interests prevent them from moving beyond a consensus scheme.

In this respect, $\mathrm{ARF}$ and $\mathrm{APEC}$ share similar problems. However, some authors argue that ARF has actually been "an ASEAN initiative whose creation the Chinese were powerless to prevent. China joined the ARF not least so it could put a brake on initiatives that the Chinese saw as inimical to their interests and to try to keep other issues off the agenda." ${ }^{(37)}$ Other authors have interpreted "issues such as the unresolved threat to regional stability generated by the repeated outbreaks of haze in Southeast Asia, the lack of a timely ARF response to the crisis in East Timor, or the absence of effective regional mechanism to prevent narcotics trafficking and small-arms smuggling" as symptoms of ARF's diminishing (or nonexistent) relevance in the region. ${ }^{(38)}$ It might be reasonable to conclude that with its current membership, powers, and institutions the ARF will have difficul- ty playing more then a consultative role. However, to a considerable extent ARF's success also depends on Chinese and American attitudes. Both countries initially opposed the idea of a rational multilateral security forum, and even after deciding to join, they have remained reluctant players in it. ${ }^{(39)}$

Once China stopped considering ARF a "tool in the hands of the Western powers for interfering in the domestic affairs of the Asian member states," ARF became an "important vehicle for airing its own security perceptions and advancing its security interests." ${ }^{(40)}$ Indeed, China has recently used $\mathrm{ARF}$ meetings to convince Asian partners that it was a responsible country rather then one interested in destabilizing the region.

For the United States, ARF has been useful, first of all to confirm US interest in the East Asian region. Secondly, the Clinton administration noticed that there were no benefits to opposing this initiative, and rather little cost and some gain in joining it. ${ }^{(41)}$ Thirdly, ARF Summits have become useful for monitoring the Chinese threat in the region.

However, over the years neither China nor the United States has been able to influence ARF as much as they intended, and neither has ever gained a leading position within the forum, as a result of which ARF has lost its potential for active conflict resolution and has been relegated to mere confidence building.

\section{China and ASEAN+3: Building new Asian borders}

ASEAN +3 is a regional framework created by ASEAN countries, China, Japan, and South Korea in 1997, initially aimed at sharing the burden of the Asian financial crisis. Even though it was initially a very informal gathering, after a few meetings the ASEAN+3 Summits became regu-

34. Shaun Narine, op. cit., p. 105, Bandar Seri Begawan, The ASEAN Regional Forum: $A$ Concept Paper, August 1995. < http://www.aseansec.org/3826.htm>. Accessed 28 August 2008.

35. Walter Mattli, The Logic of Regional Integration: Europe and Beyond, Cambridge, Cambridge University Press, 1999, pp. 168-169.

36. Walter Mattli, op. cit., pp. 169.

37. Andrew Mack, Proliferation in Northeast Asia, Occasional Paper n. 28, Washington, Henry L. Stimson Centre, 1996

38. Melissa Curley et. al., "Advancing East Asia regionalism: An introduction," in Melissa Curley et. al., op. cit., pp. 12-14.

39. Evelyn Goh et. al., "The ARF and security regionalism," in Melissa Curley et. al., op. cit., pp. 96-7.

40. Ibid., p. 98.

41. Ibid., pp. 102-3. 
larised, and the institutionalisation of the new grouping began. ${ }^{(42)}$

Generally speaking, this new forum was created for two reasons. From a pure economic perspective, adding countries such as China, Japan, and South Korea to ASEAN was intended to diversify the economies of the region by taking advantage of more complementarities and attracting powerful countries that could share the cost of re-launching Asian economic growth - not only in terms of trade balance but also by expanding industrial and infrastructural investment within the region. From a political perspective the choice of these three countries was meant to forge "a more coherent grouping of East Asian states," and at the same time prevent any of them from gaining hegemonic status in the region. ${ }^{(43)}$ ASEAN+3 made it possible to engage China in another multilateral scheme and also boost the ASEAN-Japan relationship. Finally, it was broadly recognized that "ASEAN's desire to secure itself against future crises could not be realized unless the Northeast Asian countries were included." (44) Earlier in this paper, CAFTA (China-ASEAN Free Trade Agreement) was introduced as a symbol of China's importance in the Asian regional economy, and as "an important practical step in fostering closer economic integration." ${ }^{(4)}$ In reality, CAFTA played a crucial role in achieving other aims as well. ${ }^{(46)} \mathrm{As}$ "Japan was originally very reluctant to join the ASEAN +3 process for fear of antagonizing the United States," but at the same time "could not afford to let China gain an uncontested leadership position in the region," Japan chose economic integration as a compromise and started discussing regional free trade agreements (FTA) as well. After signing several bilateral FTAs with Singapore in 2002 and with Thailand, the Philippines, and Malaysia in 2003, during the Bali Summit (2003), Japan and ASEAN agreed to set up a Closer Economic Partnership to strengthen their economic integration. A Japan-ASEAN FTA approved in 2007 should be completed by the end of 2008. ${ }^{(47)}$

The first full ASEAN +3 meeting of all 13 members was organized in 1999 in the Philippines, and on this occasion the Joint Statement on East Asian Cooperation was issued, which stated that:

...mindful of the challenges and opportunities in the new millennium, as well as the growing regional interdependence in the age of globalization and information, (the ASEAN+3 countries) agreed to promote dialogue and to deepen and consolidate collective efforts with a view to advancing mutual understanding, trust, good neighborliness and friendly relations, peace, stability and prosperity in East Asia and the world. ${ }^{(48)}$

From this statement it is evident that even this association was not seen as contributing to the regional integration process. Indeed, while all countries accepted mutual respect for sovereignty, non-interference in each other's internal affairs, and consensus as a decision-making mechanism, all made it clear that they were not interested in anything beyond economic cooperation, as the economy was considered the only area in which a cooperative strategy could succeed without imposing on the sovereignty of any state. Indeed, while the ASEAN +3 grouping has progressively enlarged its areas of cooperation to include agriculture, labour, environment, tourism, health, and information technology, the strategies in these areas seldom go beyond declarations of intents.

In 1997, a debate started at the ASEAN level "over whether or not to reform the organization's policy of nonintervention," following the suggestion of then Malaysian Deputy Prime Minister Anwar Ibrahim to push for "closer ties between the newer, less economically developed states and their wealthier counterparts, as well as for the creation of more robust political and legal institutions and a concomitant development of civil society." ${ }^{(49)}$ However, this idea was set aside as soon as the Asian financial crisis revealed how interdependence caused one state's problems to affect all of its neighbours. Since then, any attempt to discuss reforms or

42. Akihiko Tanaka, "The development of the ASEAN+3 framework," in Melissa Curley et. al., op. cit., p. 63.

43. Melissa Curley et. al., "Advancing East Asia regionalism: An introduction," in Melissa Curley et. al., op. cit., p. 1.

44. Ibid., pp. 15-16.

45. Shaun Breslin, "Theorising East Asian regionalism(s)," in Melissa Curley et. al., op. cit., p. 43.

46. However, some authors affirm that Japan agreed to be involved in the ASEAN+3 framework only because the American government, at that time led by President Bill Clinton, adopted a more relaxed attitude towards Asia in general and China in particular. Richard Stubbs, "ASEAN+3: Emerging East Asian regionalism?", Asian Survey, 2002, Vol. 42, n. 3, p. 443; Akihiko Tanaka, "The development of the ASEAN+3 framework," in Melissa Curley et. al., op. cit., p. 69; Shaun Breslin, "Theorising East Asian regionalism(s)," in Melissa Curley et. al., op. cit., p. 43.

47. It is worth noting that South Korea also launched a joint study with ASEAN on a free trade agreement in March 2004, mainly out of concern regarding the impact of China-ASEAN and Japan-ASEAN FTAs on South Korea's regional trading relationships. "Japan, ASEAN to sign free trade agreement," Xinhua, 18 April 2007; "Japan, ASEAN Reaffirm Plan For Free Trade Agreement," Kyodo, 23 July 2008; Nicholas Thomas, "Developing a regional economic community," in Melissa Curley et. al., op. cit., p. 142.

48. JSEAC, Manila, 28 November 1999, <http://www.aseansec.org/5301.htm>. Accessed 29 August 2008.

49. Melissa Curley et. al., "Advancing East Asia regionalism: An introduction," in Melissa Curley et. al., op. cit., p. 9 
notions such as "flexible engagement" or "enhanced interaction," while ostensibly welcomed, has been criticised as soon as any country denounced failure to abide by the rule of non-interference. ${ }^{(50)}$

The most important bilateral relation in the ASEAN +3 context is that between China and Japan. Even though China and South Korea are still resolving some loose ends such as "the treatment of Chinese workers in South Korea-run Chinese factories and questions of historical identity and sovereignty," these issues are not as problematic as those affecting China-Japan bilateral relations. ${ }^{(51)}$ "Within this dyad, issues of history, culture and identity clash with struggles for regional influence and power. The problems posed by ongoing visits of the Japanese leadership to the Yasukunui shrine and the portrayals of wartime activities in Japanese high school textbooks frequently cause bilateral frictions." (52)

Although recent exchanges of visits by high-ranking Chinese and Japanese officials indicate an improvement in bilateral ties and mutual confidence, deeply-rooted animosity continues to hinder East Asian (and Sino-Japanese) appeasement. Even so, the creation of ASEAN+3 can be considered a step forward in terms of regional integration by dealing with some of the problems ASEAN had left unresolved. Within ASEAN, intra-regional trade has always been troublesome, as all ten nations have similar industrial outputs. The +3 formula has significantly eased this condition by increasing regional industrial complementarities. China, Japan, and South Korea, as the region's three largest economies, all represent potential markets for Southeast Asian primary products, and can boost the economies of ASEAN countries through FDI and other types of investment.

At the same time, because all three countries offer the potential of playing similar roles, ASEAN can look to any of them for boosting national growth. This achieves the aim of balancing the regional equilibrium of power, or more simply, of counterbalancing Chinese influence in the region.

\section{China and The East Asia Summit: Beyond Asian enlargement}

The East Asia Summit (EAS) is a pan-Asian forum created to complement, rather than replace, ASEAN and APEC. Unique and very new, this institution held its inaugural session in Kuala Lampur in December 2005. Its membership is quite broad and diverse (although less so than
APEC), including the ten ASEAN members, China, Japan, South Korea, India, Australia, and New Zealand.

EAS was founded as a confidence-building body and as a framework for "encourag[ing] frank and constructive exchange of views without ignoring contentious issues." ${ }^{(53)}$ While too new to show any meaningful and reliable trends within the region, EAS appears to offer the most consistent framework for Asian (economic) integration and effectively counterbalancing Chinese regional influence.

The advantage of EAS is in its presentation of itself as something new rather than as an enlargement of an existing forum. Indeed, while the "ASEAN+" label seems based on the assumption that ASEAN's door remains open to further enlargement on the path to integration, providing the new forum with a completely different name implies that once agreement is reached, the grouping will focus on deepening its internal integration, achieving mutual-beneficial results, and strengthening common identity.

As shown in previous sections, Asian nations have never stopped trying to prevent China from achieving its regional objectives, and here again, "the 'big region' of the EAS is seen as an effective means of neutralizing Chinese power." However, today's concern is that EAS might "turn out to be not much more than a talking shop exactly because of its size and diversity and because of its geostrategic role in preventing Chinese hegemony." ${ }^{(54)}$ That would condemn EAS to the same ineffectiveness experienced by APEC and ARF. From a different perspective, India's involvement extends regional economic integration to a country that shares similar economic and trade concerns with China, but also competes with it on specific strategic views and issues. Japan's recent consideration of India as a potential economic alternative to China clearly indicates that mistrust still dominates multilateral relations in the region, and that all countries are definitely interested in maintaining a balance of power in Asia that benefits all alike.

The competition between China and India is most evident in Southeast Asia, where the two countries have overlapping and conflicting interests. The ASEAN-India relationship

50. Ibid., pp. 9-10.

51. Nicholas Thomas, "China's Regional Governance: Developing Norms and Institutions"; paper presented at the workshop Governance and Regionalism in Asia, the University of Hong Kong, Hong Kong, 8-9 December 2005.

52. Ibid.

53. See Seng Tan et. al. (eds.), An Agenda for the East Asian Summi: 30 Recommendations for Regional Cooperation in East Asia, Singapore, Institute of Defence and Strategic Studies, November 2005.

54. Shaun Breslin, "Theorising East Asian regionalism(s)," in Melissa Curley et. al., op. cit., p. 44 
cannot be considered as important as the ASEAN-China one, given the inferior economic opportunities offered to Southeast Asian countries by India's lesser integration into the ASEAN framework and its less intense and widespread economic growth. Overseas Chinese communities also play a larger role than Indian communities in ASEAN countries. As a result, India's relations with ASEAN will require more time to improve, in spite of India's political importance and large potential market. Even the India-ASEAN Free Trade Agreement scheduled for 2007 failed to materialize due to problems with rules of origin and quotas. During the last meeting of ASEAN economic ministers in Singapore in August 2008, ASEAN and India finally reached a compromise for the trade-in-goods agreement, representing the first step in accomplishing their FTA process. However, Indian economic minister Kamal Nath was vague on when the details for the next two steps (negotiations over services and investments) will be defined. ${ }^{(5)}$

China and India have conflicting interests in ASEAN countries as well. Thailand has always maintained a strong relationship with India, and is one of the countries most engaged in pushing New Delhi to deepen and intensify its links within ASEAN. In Myanmar, India is expanding cooperation in the energy and trade sector as a means of preventing Yangon from falling completely under Beijing's influence. Up to now, India has managed to keep the development of Sittwa port under its control while China has been able to set up energy cooperation joint-ventures. ${ }^{(56)}$ Finally, India is attempting to rebalance Chinese influence in Malaysia and Singapore through plans to create some "Singapore-India Special Economic Zones." ${ }^{(57)}$

Within the EAS, animosity and misunderstanding between India and China corresponds with that existing between China and Japan, and to a lesser extent between South Korea and some of the other ASEAN countries. It is only reasonable, under the circumstances, that the current status and regional ambitions of Asian countries will create tensions. ${ }^{(58)}$ Even so, during the ninth ASEAN Summit in Bali in 2003, Asian leaders affirmed their mutual desire to create an ASEAN Economic Community, described as:

the realization of the end-goal of economic integration as outlined in the ASEAN Vision 2020, (whose aim is creating) a stable, prosperous and highly competitive ASEAN economic region in which there is free flow of goods, services, investment and a freer flow of capital, equitable economic development and reduced poverty and socio-economic disparities. ${ }^{(59)}$
Today's hope is that these aims will be achieved by the EAS rather than by ASEAN.

An East Asian community composed of the 16 EAS participants would represent more then 60 percent of the world's population and possess a combined GDP greater then the European Union. It could provide significantly increased trade benefits to its members, help dampen Sino-Japanese rivalry, ease the present tensions in the region over Japan's Pacific War, encourage more cooperative attitudes toward the issue of natural resource exploitation in East Asia, promote engagement over containment, and prevent domination of the region by any major power. ${ }^{(60)}$

Although ASEAN is often considered the grouping that should lead the way in forging this East Asian community, questions remain as to whether it is strong enough to play this role. This paper suggests that the emergence of a new balance of power seems a more likely and also a more suitable solution for shaping an efficient and effective East Asian Community.

\section{Conclusion}

While retracing the evolution of ASEAN, ASEAN+3, and EAS, this paper finds that two trends remain unchanged: first, China's desire to be involved in these regional groupings and its attempt to attain a dominant position within them; and second, Asian countries' intention to avoid being left out of any kind of regional integration formula. China's success in forging a "special relationship" with Southeast Asian nations has led them to perceive China as less of a

55. "ASEAN, India conclude free trade deal in goods," Xinhua, 28 August 2008

56. Ramtanu Maitra, "The energy ties that bind India, China," Asia Times, 12 April 2005, $<$ http://www.atimes.com/atimes/South_Asia/GD12Df03.html>, accessed 1 September 2008; Hari Sud, "River project to boost India-Myanmar ties," AsiaOnline, 29 April 2008 $<$ http://www.upiasiaonline.com/Economics/2008/04/29/river_project_to_boost_indiamyanmar_ties/2836/>, accessed 1 September 2008; Aneja Urvashi, "China-Bangladesh Relations: An emerging Strategic Partnership?", Institute of Peace and Conflict Studies Special Report, New Delhi, n. 33, November 2006; Malik Mohan, "China's Strategy of Containing India," Power and Interest News Report, 6 June 2006 , $<$ http://www.pinr.com/ report.php?ac=view_report\&report_id=434>, accessed: 6 June 2008.

57. Seema Gaur, "Framework Agreement on Comprehensive Economic Co-operation Between India and Asean: First Step Towards Economic Integration," ASEAN Economic Bulletin, December 2003, pp. 83-291.

58. Mohan Malik, "Delhi and Beijing tread warily," Asia Times online, 14 February 2006.

59. Declaration of ASEAN Concord II, paragraph B1, 7 October 2003.

60. Neil Francis, "For an East Asian Union," Harvard International Review, Cambridge, Fall 2006, Vol. XXVIII, n. 3, p. 76 
threat and to start pushing for deeper economic and political contacts with their powerful neighbour. The effect on regional multilateral relations has often been described as an attempt by other Asian countries to either match or counterbalance China's status.

As described in previous sections, this healthy competitive process has served to deepen regional economic integration, but a new balance of power in political and strategic cooperation in Asia remains elusive.

In terms of economic integration, China's goal of becoming the regional leader has been limited by the many other countries included in the integration bowl. Although including nations such as India, Australia, and New Zealand has served China's interests by making their minerals and raw materials more accessible for use in China's economic development, their effect on the broader balance of power in Asia cannot be underestimated. While India, Australia, and New Zealand offer a counterbalance to ASEAN countries' dependency on Chinese raw materials, Japan and South Korea offer alternatives to China as sources of foreign direct investment and as markets for exports. For other Asian countries, regional cooperation not only boosts multilateral trade flows, but also helps limit China's run for regional leadership. Indeed, China, Japan, India, and indirectly the United States, are all equally apprehensive of the regional balance of power shifting in favour of any one of them, and while China remains the most powerful country in Asia, its need to cooperate with all other nations in the region obliges it to engage in compromise.

In terms of political integration, it is often argued that the "ASEAN way of diplomacy" is the main hindrance to furthering political integration. However, this paper argues that the "ASEAN policy" style has always been to protect Asian nations from sacrificing "sovereignty or independence of action to a supranational body." ${ }^{(6)}$ The "ASEAN way of diplomacy" has from the outset been based on the Indonesian words musyawarah and mufakat (discussion and agreement; consensus and consultation), and within ASEAN it is broadly recognized that a leader should not act arbitrarily or impose his will, but rather make gentle suggestions of the path a community should follow, being careful always to consult all other participants fully and to take their views and feeling into consideration before delivering his conclusions (... as) the negotiations take place in the spirit of musyawarah are not between opponents but as between friends and brothers. ${ }^{(62)}$

Indirectly born from ASEAN, ARF, ASEAN+3, and EAS also follow the ASEAN "way of diplomacy." However, despite regular meetings and negotiations, the rule of consensus perfectly suits Asian countries, since they are not ready to accept any interference in their national policy or to see their interests succumb to a majority vote. This orientation is further confirmed by the fact that ARF, as the only regional security framework, has a merely confidence-building rather than active conflict resolution role, and that ASEAN+3 cooperation strategies seldom go beyond declarations of intent in non-economic areas.

However, since Asia has finally recognized that the status quo will not achieve the desired results, and that economic integration is critical for the region's future, it can be assumed that all Asian countries are interested in establishing an institutionalized regional forum that can help them achieving a deeper, broader, and more effective regional integration.

At the same time, Asia should avoid redundant discussion fora. In its path to integration, Europe has managed to eradicate most of its "old-fashioned" regional organizations in an effort to reduce confusion and overlapping tasks among member states and institutions. Achieving the same goal may be more difficult for Asia, but restricting dialogue to a few regional organizations is crucial to consolidating Asian regional integration. Otherwise, Asian nations will continue to abandon any summit where discussions don't go their way and set up alternative frameworks with more like-minded regional partners, thereby diminishing the importance and effectiveness of any regional framework.

Since China is currently the most powerful and influential country in Asia, it can be expected to avoid downsizing negotiations to a unique table, as this seems the only option other regional nations have to counterbalance Chinese political and economic weight, and thereby prevent China from behaving as a primus inter pares. •

61. Shaun Narine, op. cit., pp. 31.

62. Ibid., pp. 33 